Gut, 1973, 14, 535-540

\title{
Small intestinal beta-galactosidase activity in the horse
}

\author{
M. C. ROBERTS, D. E. KIDDER, AND F. W. G. HILL \\ From the Department of Veterinary Medicine, University of Bristol
}

SUMMARY Two enzymes having lactase activity are present in the equine small intestine. The first, the digestive enzyme, neutral beta-galactosidase, declines in activity from birth to three years, disappearing completely between 3 and 4 years of age. The other, the soluble lysosomal enzyme, acid beta-galactosidase, having affinity for lactose and a synthetic beta-galactoside, shows a decrease in activity in the first three months of life and thereafter varies little in activity and represents the lactase enzyme in the adult horse. This pattern may parallel the development of lactase activity in many other mammals and in the majority of the world's human population.

In foals as in many other newborn mammals, the milk sugar, lactose, is the principal energy source and is hydrolysed into the readily absorbed monosaccharides, glucose and galactose, by the enzyme, lactase (beta-galactosidase, E.C. 3.2.1. 23), located in the brush border of the enterocytes of the small intestinal mucosa (Kretchmer, 1972). Roberts, Hill, and Kidder (1973) described the distribution of lactase in the equine small intestine, and the development of the enzyme from early foetal to adult life. Differing optimum $\mathrm{pH}$ values for lactase activity from mucosal homogenates of young and adult horses indicated that more than one enzyme could be contributing to the hydrolysis of lactose.

Following the description of two enzymes with lactase act:vity in the small intestinal mucosa of the calf (Heilskov, 1956), the small intestine of many other animals has been shown to contain more than one beta-galactosidase (Asp, Dahlqvist, and Koldovský, 1969). In the rat, one of these enzymes, optimum $\mathrm{pH} 3-4$, is mainly soluble and has high affinity for the synthetic hetero betagalactosides, the other, localized in the brush border, hydrolyses lactose more rapidly than the hetero beta-galactosides and has optimum $\mathrm{pH}$ 5.5-6.0 (Asp and Dahlqvist, 1968). Three enzymes have been demonstrated in the human, the brush border digestive enzyme, neutral beta-galactosidase acting at a neutral $\mathrm{pH}$ with greater affinity for lactose, and two hetero beta-galactosidases present in the lysosomes or cytoplasm having greater

Received for publication 18 April 1973. affinity for the sythetic substrates (Asp, Dahlqvist, and Koldovský, 1970).

The purpose of the present study was to characterize the equine beta-galactosidases with respect to pH optima, substrate specificity, enzyme inhibition, differential ultracentrifugation and solubilization in small intestinal mucosa from horses early in foetal development to maturity.

\section{Materials and Methods}

\section{EQUINE MUCOSAL HOMOGENATES}

These were prepared from freshly obtained or deepfrozen samples of foetal, young foal, or adult equine small intestine (Roberts and Cotchin, 1973). The mucosa was scraped off with a metal spatula and homogenized with 40 volumes of chilled deionized water by sonication (Soniprobe, type 1130A, Dawe Instruments Ltd, England) in a tube surrounded by crushed ice. The homogenate was used immediately or stored at $-20^{\circ} \mathrm{C}$ until required and any further dilutions were made with cold deionized water.

\section{PARA CHLOROMERCURIBENZOATE (P-CMB) INHIBITION STUDIES}

The method of Koldovský, Asp, and Dahlqvist (1969) for the separate assay of acid and neutral beta-galactosidases by $\mathrm{p}-\mathrm{CMB}$ inhibition of the acid enzyme was used. The following buffered substrates were prepared: $0 \cdot 1 \mathrm{M}$ lactose solution in $0 \cdot 1 \mathrm{M}$ citrate/phosphate buffer for $\mathrm{pH} 3 \cdot 0-4 \cdot 6$, and in 0.1 M maleate buffer for pH 5.0-7.0, with and without $0.2 \mathrm{mM}$ p-CMB (parachloromercuri- 
benzoic acid, BDH Ltd, Poole), and $0 \cdot 1 \mathrm{M}$ cellobiose solutions at $\mathrm{pH} 4.2$ and 6.0 in the respective buffers with and without the presence of $0.2 \mathrm{mM}$ p-CMB. The enzyme activity was expressed as units per gram of wet mucosa per minute at $37^{\circ} \mathrm{C}$.

ASSAY OF 6-BROMO-2-NAPHTHYL BETA-GALACTOSIDASE (BNG-ASE) ACTIVITY The procedure of Dahlqvist, Bull, and Gustafsson (1965), using the substrate 6-bromo-2-naphthyl beta-galactoside (BNG), was employed. An homogenate concentration of 1 in 400 or 1 in 800 was required. Buffers covering a range $\mathrm{pH}$ 3.0-7.0 consisted of $0 \cdot 1 \mathrm{M}$ citrate/phosphate $\mathrm{pH} 3 \cdot 0-3 \cdot 4$, $0 \cdot 1 \mathrm{M}$ acetate buffer $\mathrm{pH} 3 \cdot 8-5 \cdot 4$, and $0 \cdot 1 \mathrm{M}$ maleate buffer pH 5.8-7.0 with and without the presence of $0.2 \mathrm{mM}$ p-CMB. The enzyme activity was expressed in units of micromoles of substrate hydrolysed per minute by $1 \mathrm{ml}$ of the enzyme solution.

\section{ULTRACENTRIFUGATION AND}

\section{SOLUBILIZATION}

Separation of the beta-galactosidases by ultracentrifugation and subsequent solubilization of the originally particle bound enzyme fraction with crystalline papain solution (Sigma Chemical Co, St Louis, Mo, USA) in the presence of cysteine hydrochloride (BDH Chemicals Ltd, Poole) was performed by the method of Asp et al (1969).

\section{DEFINITION OF ENZYME ACTIVITIES}

Total beta-galactosidase or lactase activity was the calculated enzyme activity determined with the substrate lactose at the stated $\mathrm{pH}$. The p-CMB resistant activity represented the neutral betagalactosidase, being the lactase activity in the presence of $\mathrm{p}-\mathrm{CMB}$ at the stated $\mathrm{pH}$, and this activity subtracted from the total activity represented the p-CMB sensitive or acid beta-galactosidase activity at that $\mathrm{pH}$.

\section{Results}

EFFECT OF P-CMB ON BETA-GALACTOSIDASE ACTIVITY IN THE EQUINE FOETUS

Mucosal homogenates from the jejunum and ileum of three foetuses were examined for beta-galactosidase activity. In the jejunal mucosa of a 4-month foetus, optimal beta-galactosidase activity was at pH $4 \cdot 2-4 \cdot 6$, the total activity being reduced by $20 \%$ at pH 6.0 (fig 1a). In the presence of the inhibitor, optimal activity was at pH $6 \cdot 0-6 \cdot 4$; this p-CMB resistant component represented almost $80 \%$ of the total activity at $\mathrm{pH} 6.0$, whereas the $\mathrm{p}-\mathrm{CMB}$ sensitive component had a pH optimum 3.8-4.2. However, in the ileal mucosa (fig 1b) both the total beta-
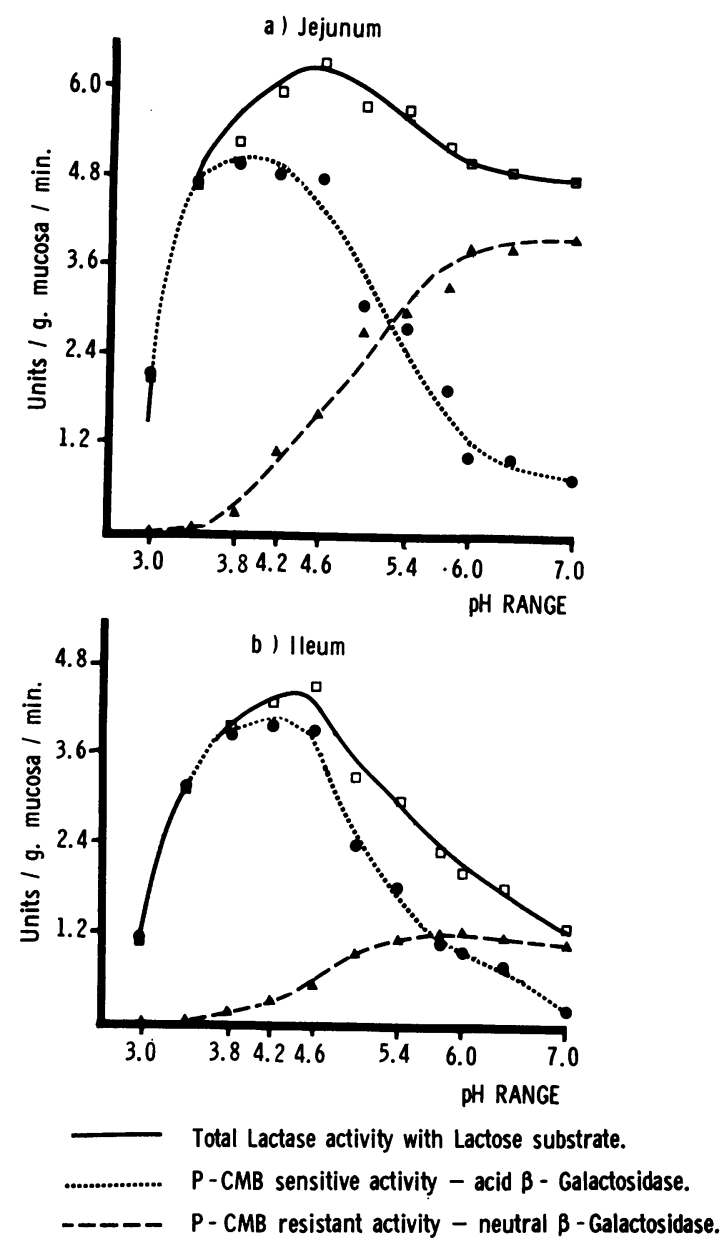

Fig 1 Effect of $p-C M B$ on the activity curves of lactase in the equine foetus (37) 175 days.

galactosidase and p-CMB sensitive enzyme had pH optima $4 \cdot 2-4 \cdot 6$, the p-CMB-resistant component having an optimum $\mathrm{pH} 6.0$ and providing $60 \%$ of the total activity at that $\mathrm{pH}$. These $\mathrm{pH}$ activity curves indicated that two distinct enzymes contributed to the total beta-galactosidase activity in the intestinal mucosa of the equine foetus, and that the proportion of acid enzyme (optimum pH 4.2) to neutral beta-galactosidase (optimum $\mathrm{pH}$ 6.0) was greater in the ileum than in the jejunum.

\section{BETA-GALACTOSIDASES IN THE YOUNG} HORSE

Mucosal homogenates from the jejunum, and occasionally the lower jejunum and ileum of nine 
horses from birth to 3 years old were examined. With lactose as substrate, optimal activity of total lactase and the p-CMB-resistant component providing over $90 \%$ of the total activity was at pH 6.0 (fig 2a). The p-CMB-sensitive acid betagalactosidase, $\mathrm{pH}$ optimum $4 \cdot 2-4 \cdot 6$, was present at a very low level. The affinity of the beta-galactosidases for BNG using the same homogenates demonstrated optimal activity of BNG-ase at $\mathrm{pH} 4 \cdot 2$, whilst in the presence of p-CMB almost complete inhibition of BNG-ase was produced throughout the $\mathrm{pH}$ range, minimal residual activity being present at $\mathrm{pH} 6.0$ (fig 2b). However, betagalactosidase activity for the beta-glucoside, cellobiose, more nearly paralleled that for lactose. Cellobiase activity had an optimum pH 6.0, was

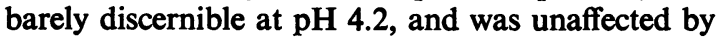
the presence of $0.2 \mathrm{mM}$ p-CMB in the substrate solution.
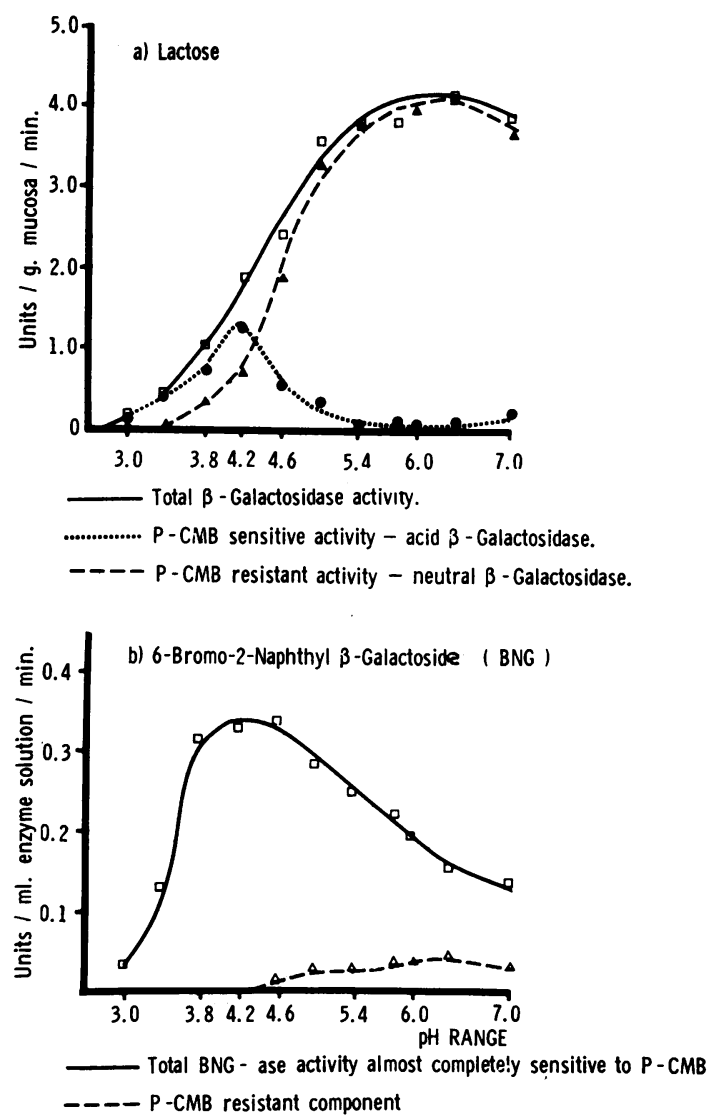

Fig 2 Beta-galactosidase activity in the jejunal mucosa of a young horse (30). Comparison of optimum $\mathrm{pH}$ with lactose and BNG as substrates.
BETA-GALACTOSIDASES OF ADULT HORSES Beta-galactosidase activity was examined in the small intestinal mucosa of seven horses over 4 years of age. Irrespective of the site sampled, optimal beta galactosidase activity in the adult small intestine occurred at $\mathrm{pH} \mathbf{4 \cdot 2}$ with lactose as substrate, the activity being $\mathbf{9 0 \cdot 7 - 9 8 . 8 \%}$ (mean $94.9 \%$ ) sensitive to $0.2 \mathrm{mM}$ p-CMB (fig 3a). Although slight residual activity was demonstrated (fig 3a), this may reflect inaccuracies with the method rather than a p-CMB-resistant enzyme. The p-CMB-sensitive acid beta-galactosidase represented virtually all the lactase determined in the

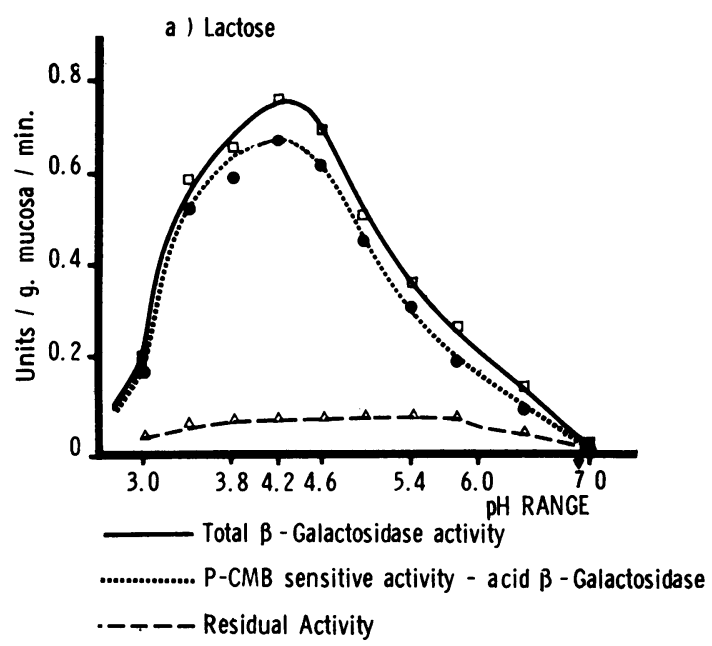

b ) 6-Bromo-2-Naphthyl $\beta$-Galactoside ( BNG )

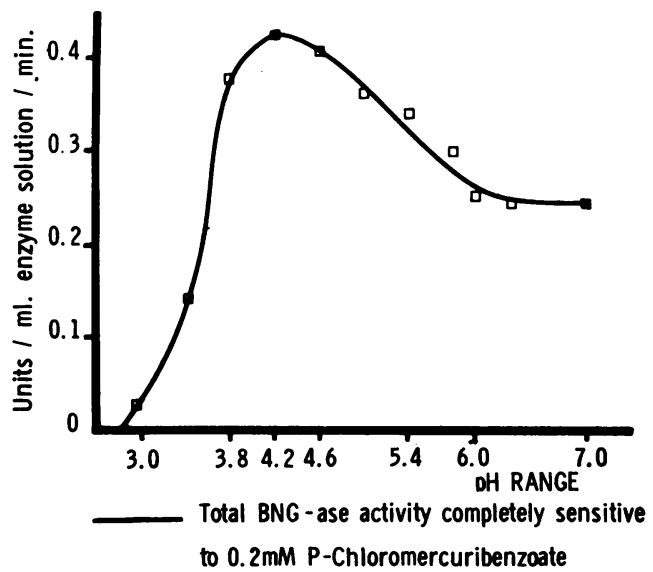

Fig 3 Beta-galactosidase activity in the jejunal mucosa of an aged horse (10). Comparison of optimum $p H$ with lactose and $B N G$ as substrates. 
mucosa of the adult. Highest levels of acid betagalactosidase were in the proximal small intestine, and this enzyme exerted $23-25 \%$ maximal activity at $\mathrm{pH} 6.0$ throughout the small intestine. With BNG as substrates enzyme activity was optimal at $\mathrm{pH}$ $4 \cdot 2$ with $55-60 \%$ of this level present at pH $6 \cdot 0$. Furthermore BNG-ase was completely inhibited by $0.2 \mathrm{mM}$ p-CMB at all pH values (fig $3 b$ ). Cellobiase was not detected in mucosal homogenates from the adult small intestine.

\section{INFLUENCE OF AGE ON BETA-GALACTOSIDASE} ACTIVITIES

Significant changes in the development of the equine beta-galactosidases occurred from early in foetal life (estimated gestational age 110 days) through to maturity (fig 4). Neutral beta-galactosidase detected in the earliest foetus reached maximum activity at birth thereafter steadily decreasing for three years, until at 4 years of age and subsequently, the enzyme could not be demonstrated in the small intestine. Acid beta-galactosidase present in the jejunal and ileal mucosa of the 110day foetus had almost trebled in activity by 228 days and further increased until birth. The proportion of acid to neutral enzyme was consistently greater in the ileal than in the jejunal mucosa. The maximum recorded activity was at 2 days of age, 6.29 units of acid beta-galactosidase compared with 14.58 units of the neutral enzyme. By 15 weeks of age, acid beta-galactosidase activity in the jejunum and ileum was 1.18 and 1.01 units respectively, the range of activity from this age to adult being 0.57 to 2.23 units determined in the presence of p-CMB at pH 4.2.

\section{LARGE INTESTINAL BETA-GALACTOSIDASE ACTIVITY}

Mucosal homogenates prepared from all sections of the caecum and colon, and assayed for lactase, had far higher activity at $\mathrm{pH} 4 \cdot 2$ than at $\mathrm{pH} \mathrm{6.0,}$ and the almost total inhibition by $0.2 \mathrm{mM}$ p-CMB indicated that the enzyme was acid beta-galactosidase.

\section{ULTRACENTRIFUGATION AND}

SOLUBILIZATION OF EQUINE

BETA-GALACTOSIDASES

When a mucosal homogenate from a young horse had been ultracentrifuged at $100000 \mathrm{~g}$ for 60 minutes only $4.8-7 \cdot 1 \%$ (mean $6.2 \%$ ) of the neutral betagalactosidase activity, but $26 \cdot 3-54 \cdot 3 \%$ (mean $42 \cdot 4 \%$ ) of the acid and $63 \%$ of the BNG-ase activity were found in the supernatant. The sediment contained $81 \cdot 3-95.2 \%$ (mean $89 \cdot 1 \%$ ) of the neutral, 13.7$67.8 \%$ (mean $42.0 \%$ ) of the acid, and $17 \cdot 4-29.2 \%$ (mean $23.3 \%$ ) of the BNG-ase activities. By contrast, from centrifuged adult mucosal homogenates the supernatant contained $54.7-60.6 \%$ (mean $57.6 \%$ ) of the acid enzyme, $50 \cdot 6-58.6 \%$ (mean $54.6 \%$ ) of the BNG-ase, some 30 to $34 \%$ of these activities being sedimented with the pellet, but the neutral enzyme was absent from supernatant and sediment.

Incubation with papain partly solubilized the originally particle-bound neutral beta-galactosidase in the young horse, the clear supernatant after further centrifugation at $100000 \mathrm{~g}$ for 60 minutes being used as the solubilized enzyme preparation. Considerable inactivation of the original activity must have occurred during incubation as only $21 \%$ of the original neutral beta-galactosidase (measured

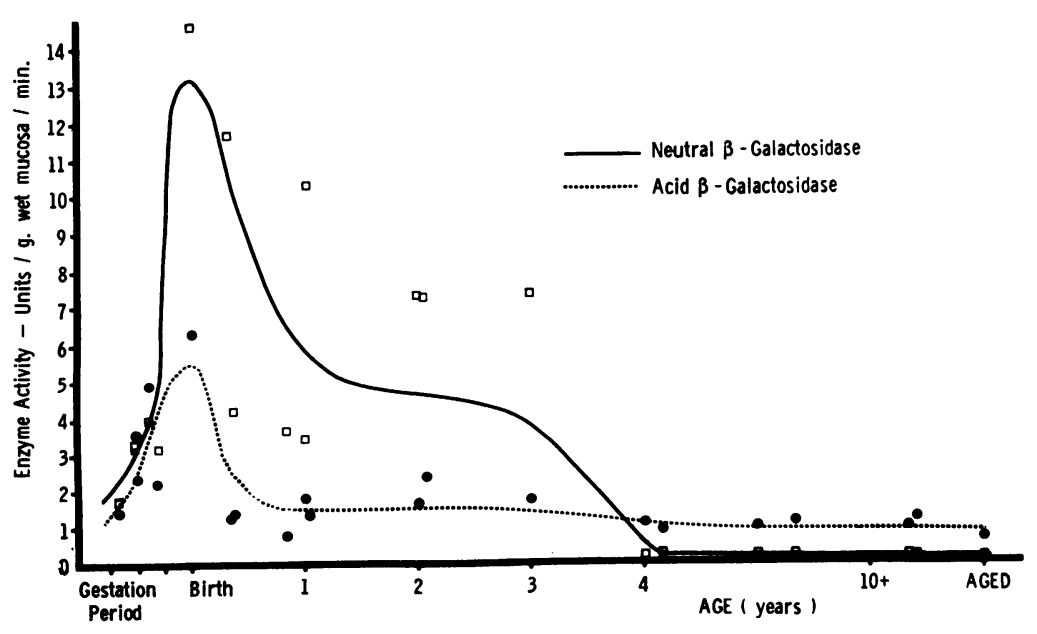

Fig 4 Development of beta-galactosidase activities in the horse. 
with lactose in the presence of p-CMB at $\mathrm{pH} 6.0$ ) appeared in the supernatant. Gel filtration chromatography of these equine enzyme fractions was markedly unsuccessful for further separation and purification.

\section{Discussion}

There is substantial evidence provided in this investigation for the existence of two beta-galactosidases hydrolysing lactose in the small intestinal mucosa of horses. The procedure adopted for their characterization in crude homogenates was based on differences in the optimum $\mathrm{pH}$, substrate specification, and sensitivity to parachloromercuribenzoate as defined by Asp and Dahlqvist (1972) in the human. Unfortunately, gel filtration chromatography did not assist the separation and partial purification of these equine enzymes (Roberts, 1972). In the foetus and in the young horse the two enzymes contributed to the $\mathrm{pH}$ activity curves whereas in the adult horse of 4 years and older only the acid beta-galactosidase was present. The neutral betagalactosidase, $\mathrm{pH}$ optimum 6.0 , was resistant to $0.2 \mathrm{mM}$ p-CMB with lactose as substrate, did not show affinity for BNG, and was at least $90 \%$ particle bound on ultracentrifugation. This enzyme represented the true lactase of the small intestine and was very similar to the neutral enzyme of the rat (Asp and Dahlqvist, 1968) and man (Asp et al, 1969). Under optimal conditions for the solubilization of human lactase only $30 \%$ of the originally particle-bound activity could be recovered in soluble form (Asp et al, 1969), this comparing with $21 \%$ for the corresponding enzyme in the young horse.

The acid beta-galactosidase present in mucosal homogenates of horses of all ages had a pH optimum $4 \cdot 2$, was sensitive to $0.2 \mathrm{mM} \mathrm{p}-\mathrm{CMB}$ in the substrate solutions, and had affinity for lactose and BNG, termed BNG-ase, with the latter substrate although exerted by the same enzyme. The enzyme represented the soluble fraction although $42 \%$ of the activity determined with lactose was sedimented after initial ultracentrifugation However, $63 \%$ of the BNG-ase activity was in the supernatant and only $23 \%$ in the sediment following centrifugation comparable with the findings for human BNG-ase activity (Asp et al, 1969) This equine acid betagalactosidase showed similarities to the acid enzyme described in the rat (Koldovský et al, 1969), the pig (Sato and Yamashina, 1971), and the human (Asp, 1971). The beta-glucosidase, cellobiase, probably exerted by the same brush border enzyme responsible for lactase activity (Dahlqvist and Lindberg, 1966) was demonstrated in the small intestine of foetal and young horses but not adults. Cellobiase like the neutral beta-galactosidase had optimum pH 6.0 , was not inhibited by $0.2 \mathrm{mM}$ p-CMB, was barely discernible in mucosal homogenates from adults, and the beta-glucosidase/ neutral beta-galactosidase activity ratio was consistently 1 to 5 throughout the small intestine (Roberts, 1972) as reported in the human (Asp et al, 1969).

A third enzyme, hetero beta-galactosidase, presumably lysosomal, was described in the small intestine of the human (Asp et al, 1970), monkey (Swaminathan and Radhakrishnan, 1969), and pig (Sato and Yamashina, 1971) having an optimum pH $5 \cdot 5-6 \cdot 0$, except in the monkey, $\mathrm{pH} 7 \cdot 0$, and was inhibited by $0.2 \mathrm{mM}$ p-CMB. This enzyme, absent in the rat (Asp, 1971),was not detected in the horsealthough this absence might be dependent on the substrates used in the investigation. No specific substrate exists for the hetero beta-galactosidase (Asp and Dahlqvist, 1972); however, BNG was used because in the human, of the two lysosomal enzymes hydrolysing this substrate, the acid, but not the hetero beta-galactosidase, also hydrolysed lactose (Alpers, 1969).

The inhibition of equine acid beta-galactosidase by $\mathrm{p}-\mathrm{CMB}$ indicated that this enzyme, like the beta-galactosidase of Escherichia coli and the acid enzymes of the rat and human, was dependent on intact thiol groups for hydrolytic activity (Asp et al, 1969). This soluble enzyme, located in the enterocyte lysosomes, the number of which could affect the levels of activity in different parts of the tract (Asp, 1971), is also found in many other organs and tissues throughout the animal body usually associated with lysosomal particles (Furth and Robinson, 1965). Physiologically, the enzyme is concerned with intracellular metabolism, possibly of glycosaminoglycans or glycolipids, whereas the hetero beta-galactosidase could influence glucocerebroside metabolism (Asp, Berg, Dahlqvist, Jussila, and Salmi, 1971).

The established properties of the equine and human beta-galactosidases are compared in the table. The pattern of beta-galactosidase activity in the equine small intestine closely parallels that present in other mammals, including humans with racial lactose intolerance in traditional non-milk-drinking areas, representing the major proportion of the world's population (Kretchmer, 1972). In this condition, which becomes evident as early as 4 years of age in Bantu children, the brush border enzyme is missing or barely detectable from this age despite being present at comparable levels to normal white persons at birth whilst the acid enzyme is unaffected (Cook, 1967).

The present findings are in agreement with lactose 


\begin{tabular}{|c|c|c|c|c|c|}
\hline \multirow[t]{2}{*}{ Properties } & \multicolumn{2}{|l|}{ Equine Beta-galactosidase } & \multicolumn{3}{|c|}{ Human Beta-galactosidase } \\
\hline & Acid & Neutral & Acid & Hetero & Neutral \\
\hline Localization & $\begin{array}{l}\text { Cytoplasmic or lysosomal } \\
\text { Soluble } \\
\text { Present in supernatant } \\
\text { after centrifugation } \\
\text { at } 100000 \mathrm{~g} \text { for } 60 \mathrm{~min}\end{array}$ & $\begin{array}{l}\text { Presumably in brush } \\
\text { border } \\
\text { Particulate } \\
\text { Major fraction } \\
\text { sediments after } \\
\text { centrifugation at } \\
100000 \mathrm{~g} \text { for } 60 \mathrm{~min}\end{array}$ & $\begin{array}{l}\text { Lysosomal } \\
\text { Soluble }\end{array}$ & $\begin{array}{l}\text { Presumably } \\
\text { cytoplasmic } \\
\text { Soluble }\end{array}$ & $\begin{array}{l}\text { Presumably in } \\
\text { brush border } \\
\text { Particulate }\end{array}$ \\
\hline Substrates & Lactose, BNG & Lactose, cellobiose & $\begin{array}{l}\text { Lactose, ONPG } \\
\text { PNPG, BNG }\end{array}$ & $\begin{array}{l}\text { ONPG, PNPG } \\
\text { BNG, PG }\end{array}$ & $\begin{array}{l}\text { Lactose, ONPG } \\
\text { PNPG, cellobiose }\end{array}$ \\
\hline $\begin{array}{l}\text { Reaction with } \\
0.2 \mathrm{mM} \text { p-CMB }\end{array}$ & Inhibited & Not inhibited & Inhibited & Inhibited & Not inhibited \\
\hline pH Optimum & $4 \cdot 2$ & 6.0 & $4-4 \cdot 5$ & $5 \cdot 5-6 \cdot 0$ & $5 \cdot 5-6 \cdot 0$ \\
\hline $\begin{array}{l}\text { Activity at } \\
\text { acid pH } \\
\text { optimum }\end{array}$ & Maximal & $\begin{array}{l}26 \% \text { of activity } \\
\text { at } \mathrm{pH} 6.0 \\
\text { (in young horse) }\end{array}$ & Maximal & Probably none & Negligible \\
\hline $\begin{array}{l}\text { Activity at } \\
\text { neutral } \\
\text { pH optimum }\end{array}$ & $\begin{array}{l}23 \% \text { of activity } \\
\text { at pH } 4 \cdot 2\end{array}$ & Maximal & $\begin{array}{l}25 \% \text { of activity } \\
\text { at } \mathrm{pH} 4.2\end{array}$ & Maximal & Maximal \\
\hline
\end{tabular}

Table A comparison of some of the properties of equine and human small intestinal beta-galactosidases

tolerance tests performed on adult horses (Roberts, 1972), which revealed no increase in plasma glucose levels, although a marked elevation occurred on dosing with the constituent monosaccharides, further confirming the absence of a functional lactose-hydrolytic enzyme in the small intestine of the adult horse. Some of the horses exhibited signs of mild abdominal discomfort and transient diarrhoea after the lactose load, whereas younger horses were able to digest this disaccharide.

This work was supported initially by the award of a research training scholarship to $M$. C. Roberts by the Horse Race Betting Levy Board, and more recently by a grant from the Trustees of the Wellcome Trust. The technical assistance of Miss M. McAvoy was greatly appreciated.

\section{References}

Alpers, D. H. (1969). On $\beta$-galactosidase activity. Gastroenterology, $56,985-986$.

Asp, N.G. (1971). Human small-intestinal $\beta$-galactosidases: separation and characterization of three forms of an acid $\beta$-galactosidase. Biochem. J., 21, 299-308.

Asp, N. G., Berg, N. O., Dahlqvist, A., Jussila, J., and Salmi, H. (1971). The activity of three different small-intestinal $\beta$ galactosidases in adults with and without lactase deficiency. Scand. J. Gastroent., 6, 755-762.

Asp, N. G., and Dahlqvist, A. (1968). Rat small-intestinal $\beta$-galactosidases: separation by ion-exchange chromatography and gel filtration. Biochem. J., 106, 841-845.
Asp, N. G., and Dahlqvist, A. (1972). Human small intestine $\beta$ galactosidases: specific assay of three different enzymes. Analyt. Biochem., 47, 527-538.

Asp, N. G., Dahlqvist, A., and Koldovský, O. (1969). Human smallintestinal $\beta$-galactosidases: separation and characterization of one lactase and one hetero $\beta$-galactosidase. Biochem. J., 114, 351-359.

Asp, N. G., Dahlqvist, A., and Koldovský, O. (1970). Small intestinal $\beta$-galactosidase activity. Gastroenterology, 58, 591-593.

Cook, G. C. (1967). Lactase activity in newborn and infant Baganda. Brit. med. J., 1, 527-530.

Dahlqvist, A., Bull, B., and Gustafsson, B. E. (1965). Rat intestinal 6-bromo-2-naphthyl glycosidase and disaccharidase activities. 1. Enzymic properties and distribution in the digestive tract of conventional and germ-free animals. Arch. Biochem., 109, $150-158$.

Dahlqvist, A., and Lindberg, T. (1966). Development of the intestinal disaccharidase and alkaline phosphatase activities in the human fetus. Clin. Sci., 30, 517-528.

Furth, A. J., and Robinson, D. (1965). Specificity and multiple forms of $\beta$-galactosidase in the rat. Biochem. J., 97, 59-66.

Heilskov, N. S. C. (1956). Studier over animalsk lactase, p. 140. Munksgaard, Copenhagen.

Kretchmer, N. (1972). Lactose and lactase. Sci. Amer., 227, 71-78.

Koldovsky,, O., Asp, N. G., and Dahlqvist, A. (1969). A method for the separate assay of 'neutral' and 'acid' $\beta$-galactosidase in homogenates of rat small-intestinal mucosa. Analyt. Biochem. 27, 409-418.

Roberts, M. C. (1972). Studies on the digestion and absorption of carbohydrates in the equine small intestine. $\mathrm{PhD}$ Thesis, University of Bristol.

Roberts, M. C., and Cotchin, E. (1973). Globidium leuckarti in the small intestine of 3 horses. Brit. vet. J., 129, 146-150.

Roberts, M. C., Hill, F. W. G., and Kidder, D. E. (1973). The development and distribution of small intestinal disaccharidases in the horse, Res, vet. Sci., in press.

Sato, M., and Yamashina, I. (1971). Fractionation and characterization of $\beta$-galactosidases from hog small intestine. J. Biochem., 70, 683-692.

Swaminathan, N., and Radhakrishnan, A. N. (1969). Characterization of two hetero- $\beta$-galactosidases from monkey small intestine. Arch. Biochem., 135, 288-295. 